\title{
STUDY EXPERIMENTAL UNTUK ALAT PENGERING BIJI KOPI TENAGA SURYA SISTEM KONTINU
}

\author{
Gery P. Hutapea ${ }^{1 *}$, Himsar Ambarita ${ }^{2}$, Farel H. Napitupulu ${ }^{3}$, M. Syahril Gultom ${ }^{4}$ \\ ${ }^{1,2,3,4}$ Departemen Teknik Mesin, Fakultas Teknik, Universitas Sumatera Utara \\ Email: gery.pascal@gmail.com
}

\begin{abstract}
As one of renewable energy, solar energy is a source of energy that has the potential to be utilized, especially in tropical regions. One of the most commonly used uses of solar energy is drying. In this experiment the drying was carried out on coffee continually with finned flat plate media as the absorber. Using photovoltaic cells as a source of electrical energy to drain hot air into the drying chamber. The purpose of this study is to determine the efficiency of solar collectors and coffee drying chambers tested, aiming to later be used by many. This tool consists of two collectors, one collector with a slope angle of $0^{\circ}$ and the other collector with angle of $20^{\circ}$ and also the drying house. The collector efficiency is $78 \%$. As for the efficiency of the drying house is $79 \%$.
\end{abstract}

\begin{abstract}
Abstrak
Sebagai salah satu bentuk energi terbarukan, energi surya merupakan salah satu sumber energi yang berpotensi untuk dimanfaatkan terutama di daerah beriklim tropis. Salah satu pemanfaatan energi surya yang paling sering digunakan yaitu pengeringan. Dalam penelitian kali ini pengeringan dilakukan secara kontinu pada kopi dengan media pelat datar bersirip sebagai absorbernya. Menggunakan sel photovoltaic sebagai sumber energi listrik untuk mengalirkan udara panas ke ruang pengering. Adapun tujuan penelitian ini adalah mengetahui efisiensi solar kolektor dan ruang pengering kopi yang diuji, bertujuan agar nantinya dapat digunakan oleh khalayak banyak. Alat ini terdiri dari dua buah kolektor yaitu satu kolektor dengan sudut kemiringan $0^{\circ}$ dan yang satu kolektor lain dengan sudut $20^{\circ}$ serta rumah pengeringnya. Besar efisiensi kolektor yaitu sebesar 78\%. Sedangkan untuk efisiensi rumah pengering adalah sebesar $79 \%$.
\end{abstract}

\section{I.PENDAHULUAN}

Di era saat ini, proses produksi kopi sendiri untuk bisa dikonsumsi terbilang cukup panjang. Mulai dari pemetikan biji kopi, sudah bisa mempengaruhi.kualitas rasa kopi nantinya. Salah satu proses yang tidak kalah penting adalah proses pengeringan. Pengeringan biji kopi dilakukan sebelum tahap akhir roasting dilakukan. Maka dari itu perlu adanya solusi untuk mengatasi permasalahan tersebut dengan membuat suatu alat sebagai media pengering dan juga penjaga keadaan udara. Dengan memanfaatkan energi surya pada siang hari sebagai sumber panas yang ditangkap pada kolektor pelat bersirip, diharapkan dapat menjadi sumber panas yang lebih baik dibandingkan penjemuran langsung. Dan desain ruangan yang bisa menjaga kondisi udara pada malam hari dengan adanya desikan akan menjaga kelembapan udara dalam ruangan.

\section{II.TEORI DASAR}

\subsection{Energi Surya}

Energi surya adalah salat satu sumber energi terbarukan dan berkelanjutan karena keberadaanya yang tidak akan habis. Energi surya sampai ke bumi dalam bentuk energi panas 
dengan prinsip perpindahan panas radiasi. Sebagai energi terbarukan, energi surya semakin lama semakin dikembangkan agar bisa dimanfaatkan lebih lagi. Matahari mempunyai diameter $1,39 \times 10^{9} \mathrm{~m}$. Bumi mengelilingi matahari dengan lintasan berbentuk ellipse dan matahari berada pada salah satu pusatnya. Jarak rata-rata matahari dari permukaan bumi adalah $1,49 \times 10^{11} \mathrm{~m}$. Lintasan bumi terhadap matahari berbentuk ellipse, maka jarak antara bumi dan matahari adalah tidak konstan. Karena adanya perbedaan jarak ini, menyebabkan radiasi yang diterima atmosfer bumi juga akan berbeda.

\subsection{Teori Dasar Matahari}

Matahari mempunyai diameter $1,39 \times 10^{9} \mathrm{~m}$. Bumi mengelilingi matahari dengan lintasan berbentuk elipse dan matahari berada pada salah satu pusatnya, jarak rata-rata matahari dari permukaan bumi adalah $1,49 \times 10^{11} \mathrm{~m}$. Daya radiasi rata-rata yang diterima atmosfer bumi yaitu $\left(G_{s c}\right) 1367 \mathrm{~W} / \mathrm{m}^{2}$. Berikut adalah gambar yang menunjukan jarak antara matahari dengan bumi.

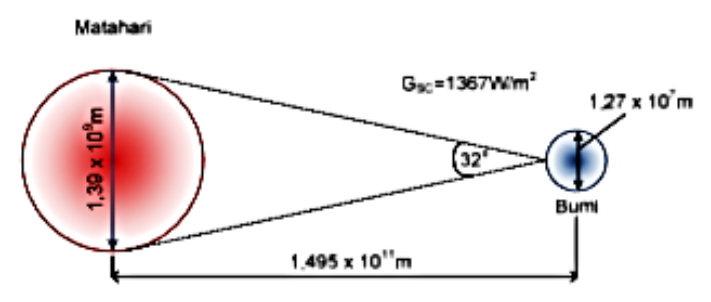

Gambar 2.2 Jarak antara matahari dan bumi

\subsection{Pemanfaatan Energi Surya}

Dalam era ini, penggunaan sumber daya alam yang tidak dapat diperbaharui semakin meningkan seiring dengan jumlah populasi manuasi yang meningkat juga, kemajuan teknologi dan lain-lain. Namun ketersedian akan sumber daya alam yang dapat diperbarui berbanding terbalik dengan sumber daya alam yang tidak dapat diperbarui. Sehingga para ilmuwan telah mencoba mengembangkan potensi sumber daya alam yang dapat diperbaharui contohnya air, angin dan energi surya.

\subsection{Pengeringan Tenaga Surya (Solar Dryer)}

Pengering tenaga surya (solar dryer) adalah cara pengeringan dengan memanfaatkan energi matahari menggunakan kolektor sebagai penyerap panas yang menjadikan penggunaan energi matahari yang lebih maksimal. Sistem pengering tenaga surya terdiri dari dua bagian utama yaitu kolektor surya dan ruang pengering. Kolektor matahari merupakan sebuah alat yang mampu menyerap sinar radiasi matahari, sehingga dapat memanaskan udara yang ada di dalam 
ruang kolektor tersebut. Panas di dalam ruang kolektor dapat digunakan untuk berbagai keperluan salah satunya adalah untuk pengeringan di dalam bidang pertanian dan lainya. Penyerapan energi radiasi surya memerlukan peralatan khusus yang terdiri dari dua macam yaitu pengumpul pelat datar dan pengumpul konsentrator.

\subsection{Kolektor Surya}

Pengering surya adalah suatu sistem pengering yang memanfaatkan energi surya. Sistem pengering surya terdiri dari dua bagian utama yaitu kolektor surya dan ruang pengering. Kolektor surya adalah suatu alat yang dapat mengumpulkan atau menyerap radiasi surya dan mengkonversikan menjadi panas.

\subsection{Teori Perpindahan Panas}

Panas adalah salah satu bentuk energi yang dapat dipindahkan dari suatu tempat ke tempat lain, tetapi tidak dapat diciptakan atau dimusnahkan sama sekali. Dalam suatu proses, panas dapat mengakibatkan terjadinya kenaikan suhu suatu zat dan atau perubahan tekanan, reaksi kimia dan kelistrikan. Perpindahan kalor/panas (heat transfer) ialah ilmu untuk meramalkan perpindahan energi yang terjadi karena adanya perbedaan suhu di antara benda atau material.

\subsubsection{Perpindahan Panas Konduksi}

Setiap kali gradien suhu terdapat pada sebuah media padat atau solid, panas akan mengalir dari daerah dengan suhu lebih tinggi ke daerah bersuhu lebih rendah. Besarnya laju dari perpindahan panas konduksi, $q_{k}$, sebanding dengan gradient suhu $d T / d x$ dikalikan dengan luas bidang panas dipindahkan, $A$.

$$
q_{k} \propto A \frac{d T}{d x}
$$

Pada hubungan tersebut, $\mathrm{T}(\mathrm{x})$ merupakan temperature local dan $\mathrm{x}$ merupakan jarak pada arah pergerakan perpiundahan panas. Laju aliran panas bergantung pada konduktifitas termal $\mathrm{k}$, yang merupakan salah satu sifat fisik dari media. Untuk konduksi melalui media homogen, laju perpindahan dirumuskan dengan hukum Fourier :

$$
q_{k}=-k A \frac{d T}{d x}
$$

\subsubsection{Perpindahan Panas Konveksi}

Konduksi dan konveksi adalah membutuhkan media perantara dalam proses perpindahan panasnya. Namun pada konveksi membutuhkan gerakan fluida untuk dapat memindahkan panas. Penelitian menunjukkan bahwa perpindahan panas konveksi sangat bergantung pada sifat-sifat fluida seperti viskositas dinamis $\mu$, konduktivitas termal $k$, massa jenis $\rho$, dan spesifik panas $C_{p}$, dan dipengaruhi oleh kecepatan fluida $V$. Konveksi juga bergantung pada bentuk dan kekasaran permukaan, dan bahkan juga dipengaruhi oleh tipe aliran seperti laminar atau turbulen. Sehingga dapat disimpulkan bahwa perpindahan panas secara konveksi adalah kompleks karena bergantung pada banyak variabel. Oleh karena itu, konveksi adalah 
mekanisme perpindahan panas yang paling kompleks. Meskipun konveksi adalah kompleks, setelah diamati bahwa laju perpindahan panas secara konveksi berbanding lurus dengan perbedaan temperatur dan dapat ditulis dengan Hukum Newton tentang pendinginan. Berikut adalah skematik perpindahan panas secara konveksi :

$$
T_{s}>T_{\infty}
$$

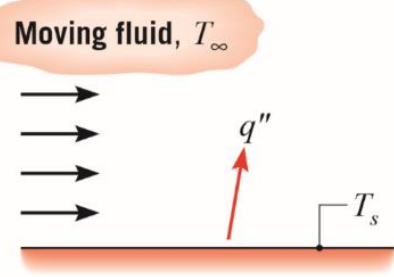

Gambar 2.4 Perpindahan panas secara konveksi

Untuk nilai perpindahan panas secara konveksi dapat di tentukan dengan rumus:

$$
q_{\text {konveksi }}=h A_{s}\left(T_{s}-T_{\infty}\right)
$$

dengan $\quad h$ : koefisien perpindahan panas konveksi $\left(\mathrm{W} / \mathrm{m}^{2} \mathrm{~K}\right)$

$A_{s}:$ luas permukaan perpindahan panas $\left(\mathrm{m}^{2}\right)$

$T_{s}:$ temperatur permukaan benda $(\mathrm{K})$

$T_{\infty}$ : merupakan temperatur lingkungan sekitar benda

\subsubsection{Perpindahan Panas Radiasi}

Radiasi berbeda dengan mekanisme perpindahan panas secara konduksi dan secara konveksi. Perpindahan panas secara radiasi tidak membutuhkan kehadiran suatu material sebagai media perantara perpindahan panas. Faktanya, energi yang ditransfer dengan radiasi adalah yang tercepat (secepat kecepatan cahaya) dan dapat terjadi pada ruangan vakum. Perpindahan panas secara konduksi dan konveksi terjadi dari temperatur yang tinggi ke temperatur yang lebih rendah. Pada radiasi, perpindahan panas dapat terjadi pada 2 benda yang memiliki temperatur yang tinggi dan dipisahkan oleh benda yang memiliki temperatur yang lebih rendah. Berikut merupakan skematik proses terjadinya perpindahan panas secara radiasi :

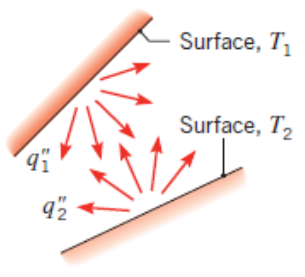

Gambar 2.18 Proses Perpindahan Panas Radiasi

\subsubsection{Perpindahan Panas Menyeluruh}

Dalam penghitungan koefisien pindahan panas menyeluruh efek radiasi apapun biasanya termasuk didalam koefisien perpindahan panas konveksi. Dimana koefisien pindahan panas melalui dinding dinyatakan sebagai berikut :

$$
q=\frac{T_{A}-T_{B}}{1 / h_{1} A^{+} \Delta x / k A^{+1 / h_{2} A}}
$$


Dimana $T_{A}$ dan $T_{B}$ masing-masing adalah suhu fluida pada kedua sisi dinding. Koefisien pindahan panas menyeluruh $\mathrm{U}$ didefenisikan oleh hubungan :

$$
\mathrm{q}=U A \Delta T_{\text {menyeluruh }}
$$

dimana $A$ merupakan luas bidang aliran kalor. Jaringan tahanan panas dihubungkan dengan proses perpindahan panas ini yang terdiri dari dua tahanan panas konveksi dan satu tahanan panas konduksi seperti yang ditunjukkan oleh gambar berikut.

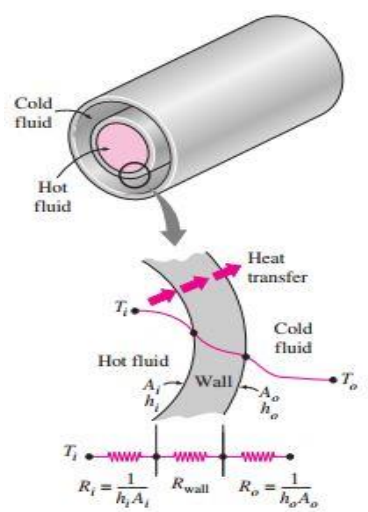

Gambar 2.20 Jaringan Tahanan Panas Pada Alat Penukar Kalor

\subsection{Teori Dasar Solar Dryer}

Solar Dryer adalah salah satu jenis alat pengering yang telah banyak digunakan oleh home industry. Penggunaan alat ini dikatakan sangat ekonomis karena menggunakan tenaga matahari langsung dan tidak menggunakan listrik walaupun ada beberapa solar dryer yang menggunakan kipas sebagai penghantar panas dari solar collector. Solar dryer sangat direkomendasikan untuk pengeringan dalam skala home industry dikarenakan alat yang ekonomis dan higienis. Bahan pangan tidak akan kontak langsung dengan udara dikarenakan bahan pangan diletakkan dalam tempat yang nantinya akan dialiri udara panas kedalam ruangan. Hal tersebut mencegah terjadinya kontaminasi dari debu, asap kendaraan, maupun hewan pengganggu.

\subsection{Klasifikasi Kolektor Surya}

Berdasarkan dimensi, geometri dan penyerapannnya kolektor surya dibedakan menjadi tiga, yaitu:

1. Kolektor surya plat datar (Flat-plate collectors)

2. Concentrating collectors

3. Kolektor surya jenis Evacuated Reciever

\subsection{Kolektor Surya Plat Datar}

Kolektor surya plat datar adalah sebuah kolektor surya berbentuk memanjang yang dilapisi kaca hitam transparan dengan kemiringan tertentu untuk menangkap energi radiasi matahari. 
Proses penggunaannya lebih mudah dan sederhana dibanding dengan kolektor surya prismatik. Komponen-komponen sebuah kolektor surya plat datar terdiri dari permukaan "hitam" sebagai penyerap energi radiasi matahari yang kemudian dipindahkan ke fluida. Penutup tembus cahaya (kaca) berfungsi mengurangi efek radiasi dan konveksi yang hilang ke atmosfer.

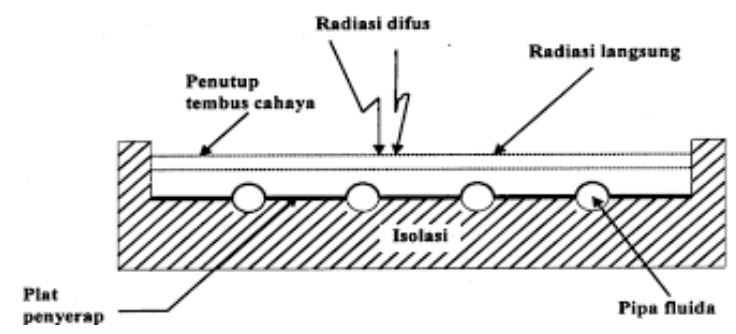

Gambar 2.24 Skema kolektor surya plat datar

\subsection{Teori dan Persamaan Dasar Sistem Kolektor Plat Datar}

Radiasi matahari diserap oleh absorber plat hitam, kemudian panas yang dihasilkan ditransfer ke fluida kerja yang mengalir dalam pipa-pipa di bawah absorber. Pemakaian absorber plat hitam tersebut dimaksudkan untuk mengisolasi energi radiasi surya yang sudah mengenai absorber dengan maksimal ditransfer ke fluida kerja. Keseimbangan energi panas pada kolektor plat datar pada persamaan berikut yaitu :

$$
Q=A_{c}\left[(\tau \alpha) \dot{e} S-U_{L}\left(T_{p m}-T_{a}\right)\right]
$$

Keterangan:

$A_{c}=$ luas permukaan kolektor $\left(\mathrm{m}^{2}\right)$

$U_{L}=$ koefisien kehilangan panas kolektor $\left(\mathrm{W} / \mathrm{m}^{2} . \mathrm{K}\right)$

$T_{p m}=$ temperatur permukaan plat $/$ Temperatur absorber $(\mathrm{K})$

$T_{a}=$ temperatur udara lingkungan/ Temperatur ambient $(\mathrm{K})$

$S \quad=$ energi radiasi matahari $\left(\mathrm{W} / \mathrm{m}^{2}\right)$

$\tau \alpha=$ koefisien transmisi-absorber

\subsubsection{Koefisien kerugian kalor total (Overall Heat Loss Coefficient)}

Kerugian kalor dari absorber terjadi pada bagian atas, samping dan bawah absorber, sehingga persamaannya menjadi:

$$
U_{L}=U_{t}+U_{b}+U_{e}
$$

Keterangan:

$U_{L}=$ koefisien kerugian kalor total

$U_{t}=$ koefisien kerugian kalor bagian atas

$U_{b}=$ koefisien kerugian kalor bagian bawah

$U_{e}=$ koefisien kerugian kalor bagian samping 


\subsubsection{Kerugian kalor bagian atas}

Panas yang hilang dari bagian atas plat penyerap karena adanya konveksi alam dan radiasi dari bagian dalam plat kolektor ke permukaan kaca.

Nilai koefisien kerugian kalor bagian atas secara teori dapat didekati dengan persamaan berikut:

$$
\begin{aligned}
U_{t} & =\frac{1}{R_{p-c 1}+R_{c 1-c 2}+R_{c 2-a}} \\
& =\frac{1}{\frac{1}{h_{c, p-c 1}+h_{r, p-c 1}}+\frac{1}{h_{c, c 1-c 2}+h_{r, c 1-c 2}}+\frac{1}{h_{w}+h_{r, c 2-a}}} .
\end{aligned}
$$

Keterangan:

$v=$ kecepatan angin di atas permukaan cover paling atas $(\mathrm{m} / \mathrm{s})$

$N=$ jumlah penutup

$\varepsilon_{c}=$ emisivitas cover

$\varepsilon_{p}=$ emisivitas plat absorber

$\sigma=$ konstanta Stefan-Boltzman $\left(5.67 \times 10^{-8} \mathrm{~W} / \mathrm{m}^{2} \cdot \mathrm{K}^{4}\right)$

$T_{p}=$ temperatur plat absorber $(\mathrm{K})$

$T_{a}=$ temperatur lingkungan $(\mathrm{K})$

\subsubsection{Kerugian kalor bagian bawah}

Kerugian kalor pada bagian bawah terjadi secara konduksi dari absorber ke panel bawah (bottom of panel), sedangkan kerugian konveksi dan radiasi diabaikan sebab nilainya lebih kecil dibandingkan kerugian secara konduksi.

Nilai koefisien kerugian kalor bagian bawah didekati dengan persamaan 2.30 berikut:

$$
U_{b}=k . L .
$$

Keterangan:

$k=$ konduktivitas termal insulator bagian bawah

$L=$ tebal insulator

\subsubsection{Kerugian Kalor Pada Bagian Samping}

Nilai koefisien kerugian kalor bagian samping juga didekati dengan persamaan 2.31 berikut:

$$
U_{e}=\frac{(U A)_{e d g e}}{A_{c}}
$$

Keterangan:

$U_{A}=\mathrm{k} / \mathrm{L} \mathrm{x}$ keliling kolektor $\mathrm{x}$ ketebalan kolektor

$A c=$ luas permukaan kolektor $\left(\mathrm{m}^{2}\right)$ 


\subsubsection{Efisiensi Kolektor}

Efisiensi dari kolektor dapat didefinisikan sebagai perbandingan antara panas yang berguna dari kolektor dengan intensitas dari radiasi surya pada persamaan sebagai berikut:

$$
\begin{gathered}
\eta=\frac{q_{u}}{S \cdot A_{c}}=F_{R}\left[(\tau \alpha)_{\mathrm{e}}-F_{R} U_{L}\left(\frac{\left(T_{i}-T_{a}\right)}{S}\right)\right] \ldots \\
\eta=\frac{q_{u}}{S \cdot A_{c}}=F^{\prime},\left[(\tau \alpha)_{\mathrm{e}}-F^{\prime} U_{L}\left(\frac{\left(T_{i}-T_{a}\right)}{S}\right)\right]
\end{gathered}
$$

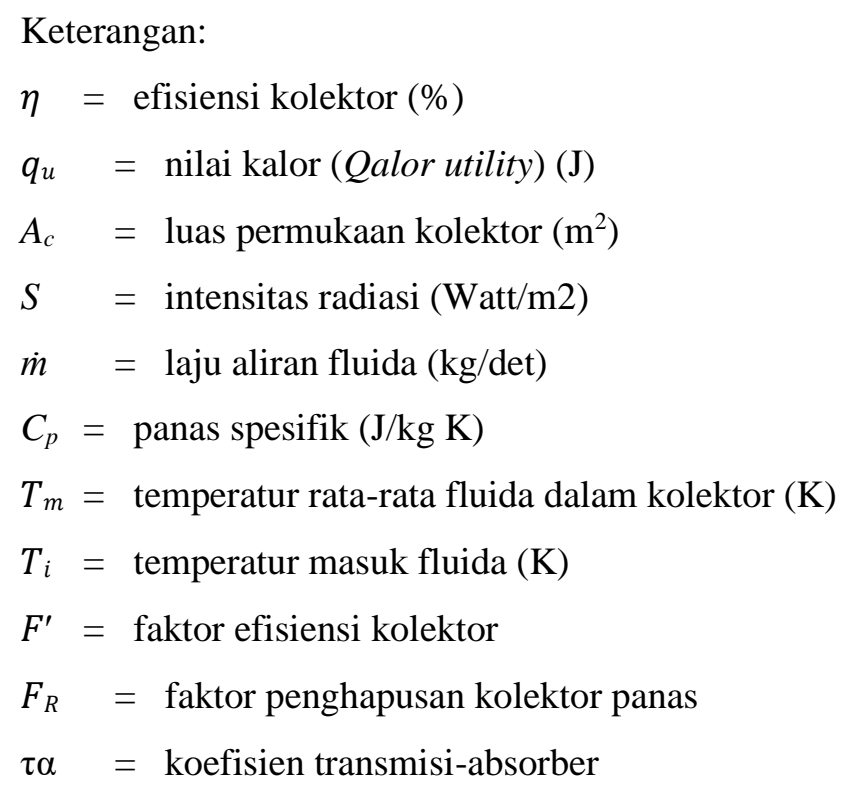

\subsection{Biji Kopi}

Biji kopi merupakan bahan dasar untuk penyeduhan kopi. Dari sekian banyak jenis biji kopi, terdapat 2 jenis biji kopi yang dijual di pasar pada umumnya, yaitu biji kopi robusta dan biji kopi arabika. Masing-masing jenis biji kopi ini memiliki keunikan dan pasarnya sendiri. Pada penelitian kali ini digunakan biji kopi arabika karena ketersediaan biji di daerah tempat penelitian.

\subsection{Proses Pengeringan Biji Kopi}

Struktur buah kopi (coffee cherry) terdiri dari pericarp (kulit daging terluar) dan biji kopi. Pericarp sendiri terdiri lagi dari beberapa lapisan seperti kulit, daging kulit, layer getah (yang biasanya terdiri dari gula alami dan semacam kandungan alkohol) dan perkamen. Lapisan pericarp adalah yang paling sering dibersihkan, namun lapisan ini juga berpengaruh dalam menambah rasa pada kopi.

\subsubsection{Pengeringan Natural (Dry Process)}


Proses ini termasuk teknik paling tua yang ada dalam sejarah proses pengolahan kopi. Setelah dipanen, ceri kopi akan ditebarkan di atas permukaan alas-alas plastik dan dijemur di bawah sinar matahari. Beberapa produsen kopi kadang menjemurnya di teras bata atau di mejameja pengering khusus yang memiliki airflow (pengalir udara) di bagian bawah. Ketika dijemur di bawah matahari, biji-biji kopi ini harus dibolak-balik secara berkala agar biji kopi mengering secara merata, dan untuk menghindari jamur/pembusukan.

\subsubsection{Pengeringan Basah (Wet Process)}

Proses ini bertujuan untuk menghilangkan semua kulit-kulit daging yang melekat pada biji kopi sebelum dikeringkan. Setelah dipanen, ceri-ceri kopi biasanya 'diseleksi' terlebih dahulu dengan merendamnya di dalam air. Ceri yang mengapung akan dibuang, sementara yang tenggelam akan tetap dibiarkan untuk proses lanjutan karena ceri-ceri demikian dianggap telah matang.

\subsection{Desikan Kalsium Klorida $\left(\mathrm{CaCl}_{2}\right)$}

Kalsium klorida $\left(\mathrm{CaCl}_{2}\right)$ merupakan garam berbentuk kristal yang mampu menyerap banyak cairan. $\mathrm{CaCl}_{2}$ terbuat dari ekstrak batu kapur. Secara umum $\mathrm{CaCl}_{2}$ dapat diaplikasikan pada industri makanan. Di dalam pengolahan limbah, $\mathrm{CaCl}_{2}$ dapat juga digunakan sebagai bahan makanan beberapa bakteri/mikroba tertentu.

\section{HASIL DAN PEMBAHASAN}

\subsection{Analisa Eksperimental}

Proses pengeringan biji kopi pada eksperimen ini berlangsung secara kontiniu dengan memanfaatkan tenaga surya.

\subsection{Hasil Pengujian Pengeringan}

Pada penempatan sensor temperatur dan kelembapan diletakkan pada setiap lapis (layer) rak. Karena pembuatan ruang pengering sejumlah 2, maka terdapat 6 sensor yang digunakan. 
Ruang 1

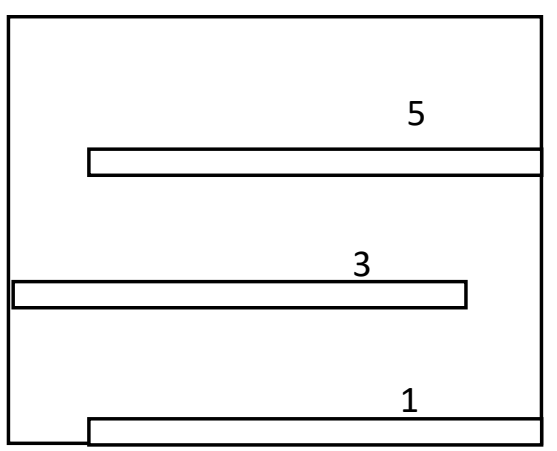

Ruang 2

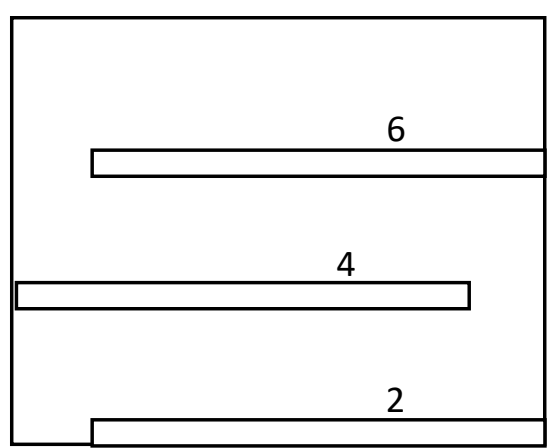

Gambar 4.1 Letak Penempatan Sensor Temperatur dan Kelembapan

\subsection{Analisis Energi Radiasi Diterima Kolektor}

Pada bagian ini akan ditampilkan perbandingan intensitas radiasi matahari secara teori dengan radiasi pengukuran.

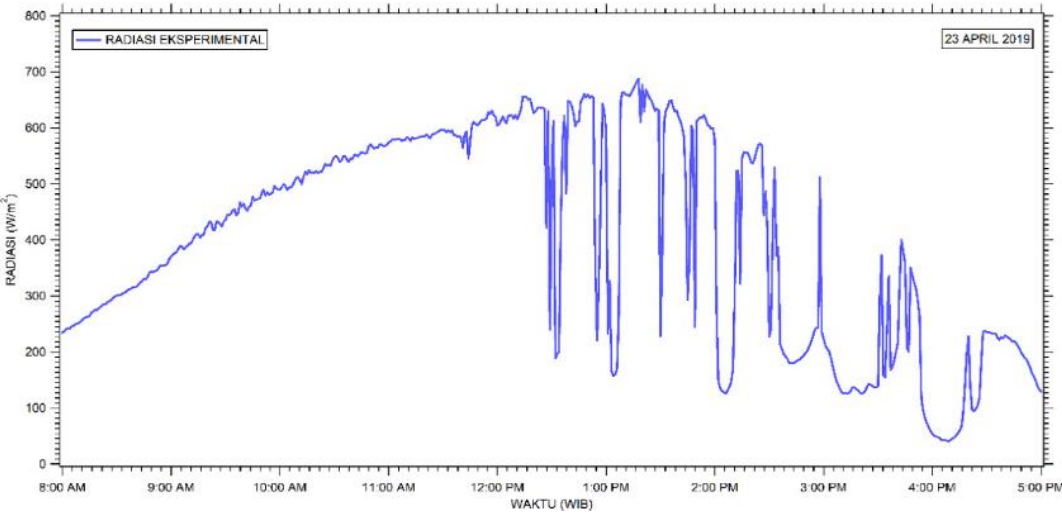

Gambar 4.8 Grafik intensitas radiasi matahari pada saat pengujian vs waktu

\subsection{Analisis Perancangan}

Analisis data yang dilakukan yaitu: menghitung panas total yang terbuang dari sistem ke lingkungan dari kolektor untul sudut $0^{\circ}$ dan $20^{\circ}$, menghitung radiasi yang diterima oleh kolektor pada sudut $0^{\circ}$ dan $20^{\circ}$, serta mengitung performansi dari kolektor secara menyeluruh.

\section{KESIMPULAN DAN SARAN}

\subsection{Kesimpulan}


Adapun kesimpulan yang didapat dari pengujian ini adalah :

1. Setelah melakukan pengujian eksperimental pada tanggal 23 April 2019 didapatkan efisiensi solar kolektor sebesar $78 \%$.

2. Dan efisiensi yang didapat pada ruang pengering sebesar $79 \%$.

\subsection{Saran}

Adapun saran untuk perbaikan pengujian ini adalah :

1. Kalibrasi pada sensor sebaiknya dipastikan sebaik mungkin agar pada saat pengukuran dilakukan data-data yang diambil tepat.

2. Sebaiknya agilent atau termokopel yang digunakan lebih banyak supaya distribusi tempratur disetiap permukaan diketahui.

\section{REFERENSI}

Ambarita, Himsar. 2011a. Energi Surya. Medan: Departemen Teknik Mesin FT USU.

Ambarita, Himsar. 2011b. Perpindahan Panas Konveksi dan Pangantar Alat Penukar Kalor. Medan: Departemen Teknik Mesin FT USU.

Tim BBC News Indonesia "Indonesia Salah Satu Penghasil Kopi Terbesar, Tapi Bukan Peminum Kopi Terbanyak" (Online) https://www.bbc.com/indonesia/majalah-43772934 (diakses 7 Mei 2019).

Duffie A. John, Beckman A. William.1980. Solar Of Thermal Processes, Second Editions. John Wiley \& Sons, Inc: New York. 


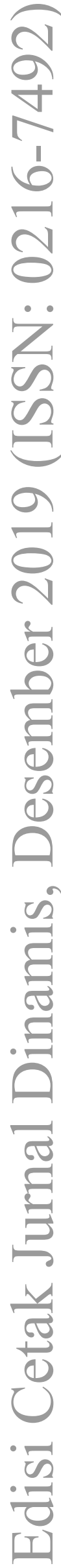

